\title{
On the taxonomic validity of Lissochlamys perstriatula (Sacco, 1897) (Bivalvia Pectinidae)
}

Mauro M. Brunetti

Calle Navas 106, 14511 Navas del Selpillar, Spain; e-mail: mbrunetti45@gmail.com

\begin{abstract}
The discovery in the Spanish lower Pliocene of Moguer (Huelva, Spain), the Guadalquivir basin, of some valves corresponding to Lissochlamys excisa var. perstriatula Sacco, 1897 is reported. The comparison with the typical material preserved in the Natural History Museum of Turin (Italy) confirmed the correspondence between the Iberian and the Italian specimens. Due to the characteristics of the sculpture and the shape of the valves which clearly differentiate it from L. excisa (Bronn, 1831), this var. perstriatula is elevated to a valid species.
\end{abstract}

KEY WORDS Bivalvia; Pectinidae; Pliocene.

Received 26.10.2019; accepted 22.12.2019; published online 30.01.2020

\section{INTRODUCTION}

Malacological research conducted in the lower Pliocene of the Guadalquivir Basin, Sands of Huelva (southern Spain) (Fig. 1) allowed the discovery of some valves of a Pectinidae corresponding to Lissochlamys excisa var. perstriatula Sacco, 1897. This variety was described for the Pliocene, probably lower, of Astigiana (Asti, Piedmont, Italy) (Sacco, 1897). In the same places where $L$. excisa var. perstriatula was found in Spain, specimens of L. excisa (Bronn, 1831) have also been found. This species had previously been reported in the Guadalquivir Basin by some authors (see Porta de, 1969, 1979 and Landau et al., 2011 for the geological framework of the area).

\section{MATERIAL AND METHODS}

The examined material was collected manually on the ground, on the surface. The following abbreviations are used in the text: $\mathrm{L}=$ maximum width of the valve; es. $=$ specimen with both valves; vl. = valve;
MRSN = Regional Museum of Natural Sciences of Turin, Italy; CBM = Brunetti Mauro collection. For the systematics we followed the WoRMS (2019).

\section{RESULTS}

\section{Systematics}

Classis BIVALVIA Linnaeus, 1758

Subclassis PTERIOMORPHIA Beurlen, 1944

Ordo PECTINIDA Gray, 1854

Superfamilia PECTINOIDEA Rafinesque, 1815

Familia PECTINIDAE Rafinesque, 1815

Subfamilia PALLIOLINAE Korobkov, 1960

Genus Lissochlamys Sacco, 1897

Type species Pecten excisus Bronn, 1831

Lissochlamys perstriatula (Sacco, 1897) (Figs. 2-5)

Lissochlamys excisa var. perstriatula - Sacco, 1897: p. 46, tav. 13, fig. 29.

Palliolum (Lissochlamys) excisum Bronn - Raffi, 1970: p. 103, tav. 25, figs. 6a-c. 


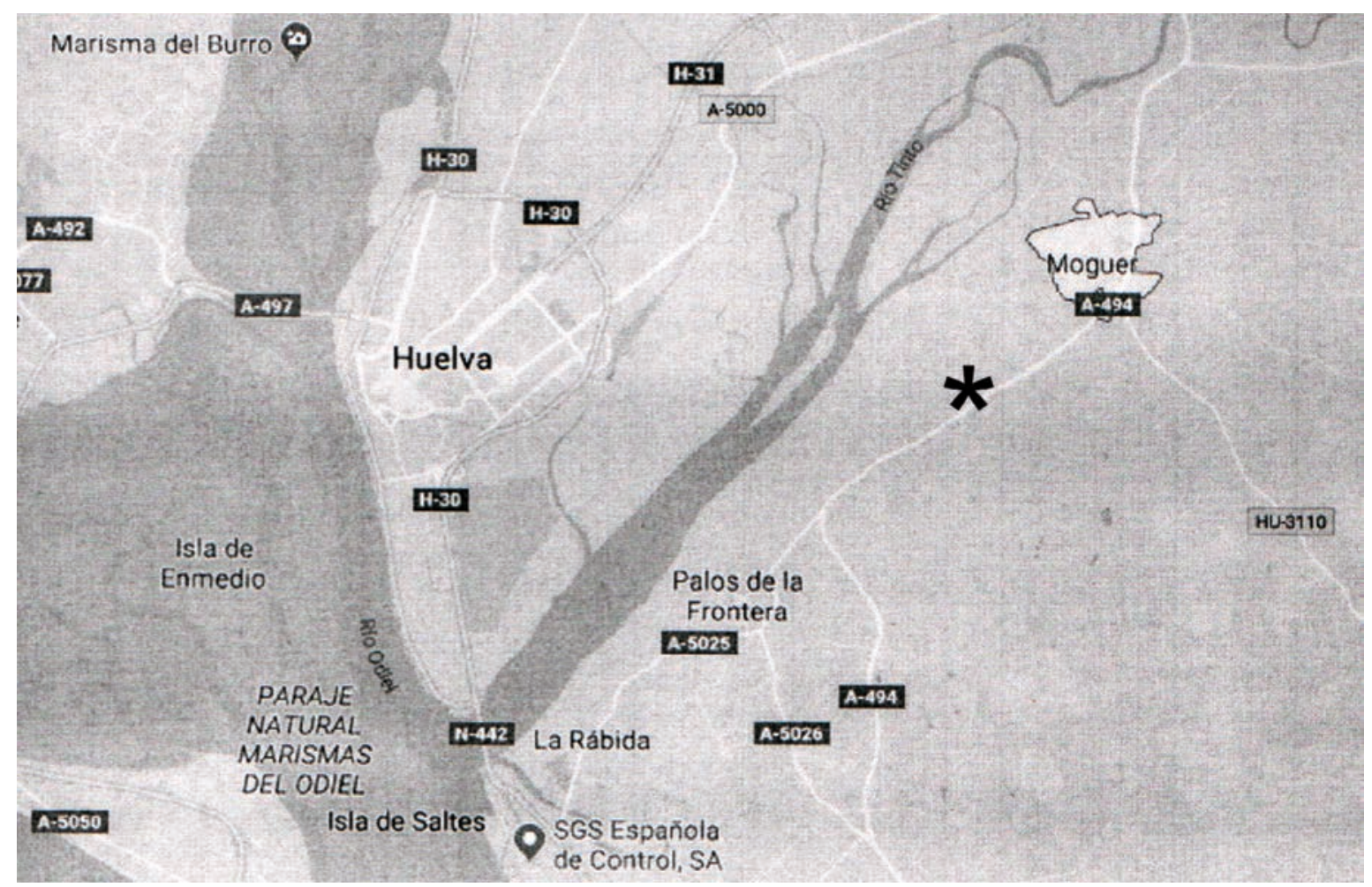

Figure 1. Study area. The asterisk indicates the locality where Lissochlamys perstriatula (Sacco, 1897) was found.

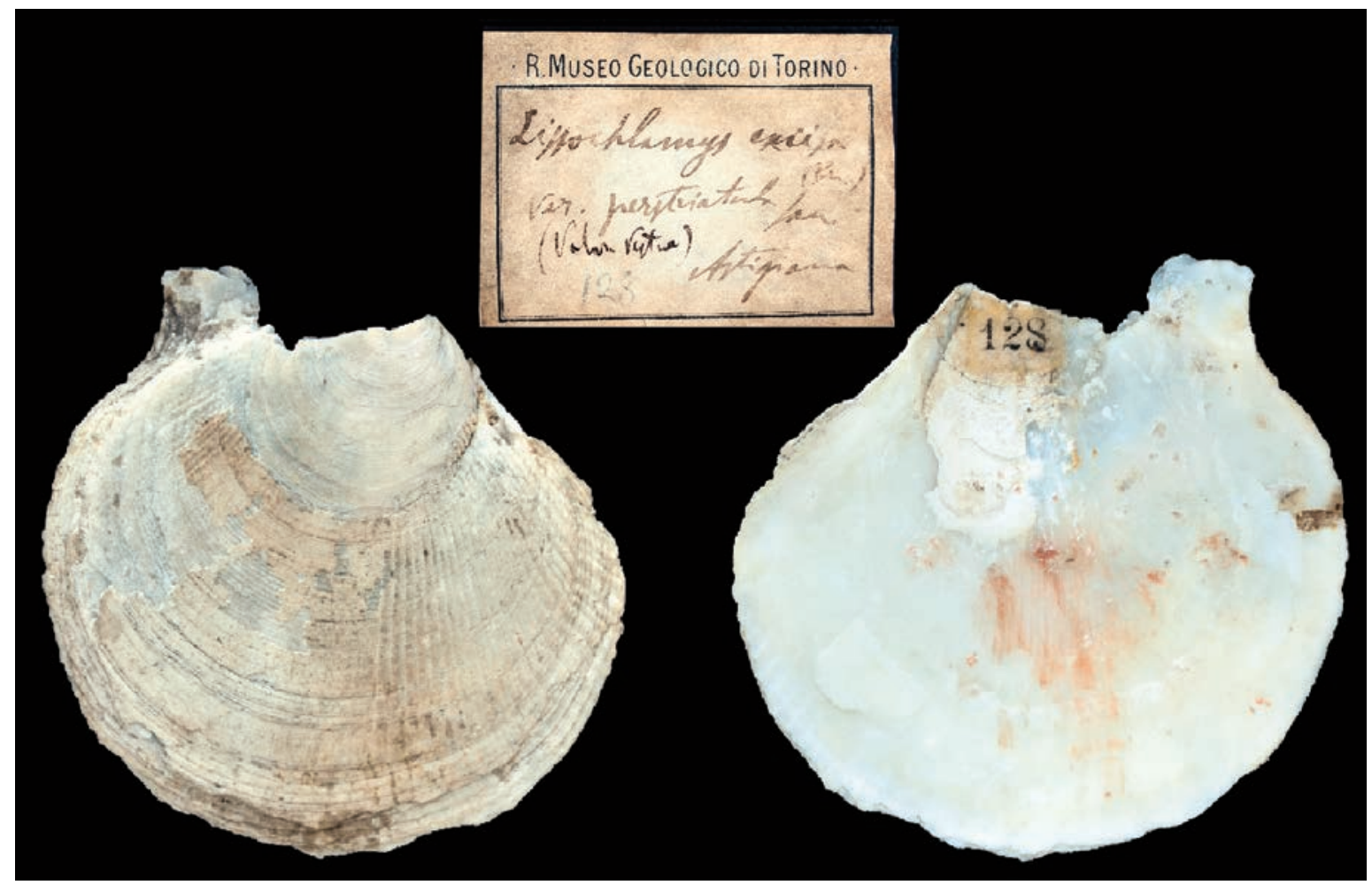

Figure 2. Lissochlamys perstriatula (Sacco, 1897). Lectotipo, Astigiana, Pliocene, L = $34 \mathrm{~mm}$, with original label. 


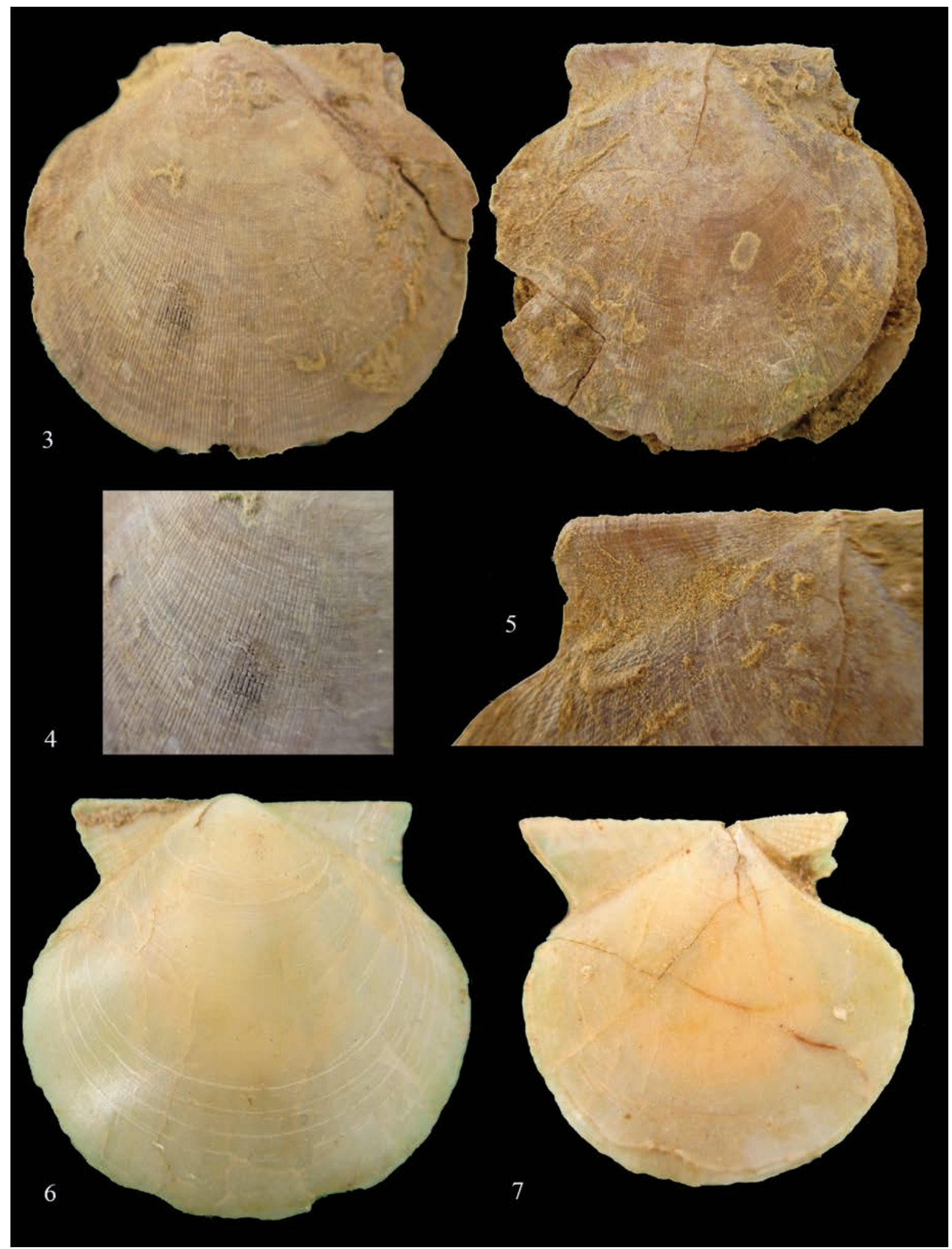

Figures 3-5. Lissochlamys perstriatula (Sacco, 1897). Fig. 3: Lissochlamys perstriatula, Moguer (Huelva, Spagna) Zanclean, $\mathrm{L}=55 \mathrm{~mm}(\mathrm{CBM})$. Fig. 4: Detail of the left valve sculpture. Fig. 5: Detail of the auricle left valve. Figures 6, 7. Lissochlamys excisa (Bronn, 1831). Fig. 6: Bonares (Huelva, Spagna), Zanclean, left valve L=51 mm (CBM). Fig. 7: Bonares (Huelva, Spagna), Zanclean, right valve $\mathrm{L}=49 \mathrm{~mm}(\mathrm{CBM})$. 
ORIGINAL DESCRIPTION. Sacco (1897): "Valva dextera radiatim striatior, in anteriore parte praecipue. Astiano: Astigiana (rara)".

EXAMINED MATERIAL. Lectotype, Astigiana, Pliocene, 1 vl. (MRSN); Moguer (Huelva, Spagna), Zanclean, 1 es. + 3 vl. (CBM).

Lissochlamys exotica (Dyllwyn, 1817). 1 vl. Cassamance (Senegal).

Description. Medium-sized shell ( $\mathrm{L}<80 \mathrm{~mm}$ ), inaequivalved. Left valve slightly convex and inaequivalved, rigth valve completely flat and subequilateral. Orthodox umboni. Palleal margin is regularly rounded, subangular at the connection with the lateral margins which are slightly concave. Sub-equal auricles, little expanded. Ornamentation consisting of a dense radial sculpture in both valves and slender shallow growth streaks. Wide muscle footprint.

Remarks. Due to the unique morphological characteristics of L. excisa var. perstriatula, it is considered here as a valid species. The lectotype (Fig. 2) of this variety consists of a somewhat worn right valve which shows a slightly coarser radial streak than the material found in the Spanish Pliocene, but which, in my opinion, falls within the variability of this species. Following the description of this taxon (Sacco, 1897), Raffi (1970, p. 103, tav. 25, figs. 6ac), illustrated a specimen also ascribable to L. perstriatula. This sample was found in the Pliocene (lower?) of Prato Otessola (Piacenza, Italy) (Cocconi collection) and it was illustrated and described as L. excisa (Bronn, 1831).

However, L. excisa has significant differences compared to $L$. perstriatula (see also the figures in Brambilla, 1976; Cavallo \& Repetto, 1992; Chirli, 2014). In particular, L. excisa (Figs. 6, 7) is devoid of radial sculpture in both valves, except for a few weak radial stria just below the auricles. This species also has the more convex right valve and the different-shaped auricles, in particular those of the right valve (Fig. 7). Among the recent species, L. perstriatula has a certain affinity with $L$. exotica (Dyllwyn, 1817), a species present in the Senegalese province (see the figures proposed by Djikstra \& Goud, 2002 and Ardovini \& Cossignani, 2004), from which it differs in the right less convex valve and the radial sculpture clearly visible and present in both valves. In $L$. exotica, this type of ornamentation is composed of much thinner radial streaks, barely visible only in the lateral parts of both valves.

In conclusion, the variety perstriatula of Sacco (1897) must therefore be considered a valid species.
The lectotype is the right valve of the Bellardi-Sacco collection with inventory number: BS-110-09-004.

\section{ACKNOWLEDGEMENTS}

My thanks go to Daniele Ormezzano and Luca Ghiraldi (Regional Museum of Natural Sciences of Turin, Italy) for the photos of the typical material, Giano Della Bella (Monterenzio, Bologna, Italy) and Valeriano Spadini (Lucignano, Arezzo, Italy), Ermanno Quaggiotto (Longare, Vicenza, Italy) and Maurizio Forli (Prato, Italy) for some suggestions.

\section{REFERENCES}

Ardovini R. \& Cossignani T., 2004. Conchiglie dell'Africa Occidentale. L'Informatore piceno, Osimo, Grafiche Scarponi, 320 pp.

Brabilla G., 1976. I Molluschi Pliocenici di Villalvernia (Alessandria). 1, Lamellibranchi. Memorie della Società Italiana di Scienze Naturali e del Museo Civico di Storia Naturale di Milano, 21: 80-128.

Cavallo O. \& Repetto G., 1992. Conchiglie fossili del Roero. Associazione naturalistica piemontese amici del Museo "F. Eusebio", Alba, Studio grafico Athena, $251 \mathrm{pp}$.

Chirli C., 2014. Malacofauna pliocenica toscana vol. 10 Bivalvia Pteriomorphia Beurlen, 1884. Tipografia Vanzi S.r.L., Colle Val d'Elsa, Siena, 220 pp.

Dijkstra H.H. \& Goud J., 2002. Pectinoidea (Bivalvia, Propeamussiidae \& Pectinidae) collected during the Dutch Cancap and Mauritania expeditions in the southeastern region ofthe North Atlantic Ocean. Basteria, 66: 31-82.

Landau B., Da Silva C.M. \& Mayoral E., 2011. The Lower Pliocene gastropods of the Huelva Sands Formation, Guadalquivir Basin, Southwestern Spain. Palaeofocus, 4: 1-90.

Porta de J., 1969. Catálogo sistemático y estratigráfico de los Pectínidos del Neógeno del NE de España (excepto Baleares). Acta Geologica Hispanica, 5: 135-142.

Porta de J., 1979. Distribución geográfica y cronoestratigráfica de Palliolum (Lissochlamys) excisum (Mollusca, Pectinidae) en España. Acta Geologica Hispanica, 14: 370-374.

Raffi S., 1970. I Pettinidi del Pliocene e Calabriano dell'Emilia occidentale (Piacentino e Parmense). Bollettino Società Paleontologica Italiana, 9: 97-135.

Sacco F., 1897. I Molluschi dei terreni terziarii del Piemonte e della Liguria. Ed. C. Clausen, Torino, vol. 22, 182 pp.

WoRMS Editorial Board, 2019. World Register of Marine Species. Available from http://www.marine species.org at VLIZ. Accessed 2019/9/30 